\title{
SPATIAL IMBALANCES IN THE UNITED KINGDOM AFTER THE MILLENNIUM: A FOCUS ON THE CITIES
}

\author{
Zsuzsanna ZSIBÓK ${ }^{\mathrm{a}}$ \\ ${ }^{a}$ Research fellow. Hungarian Academy of Sciences Centre for Economic and Regional Studies Institute \\ for Regional Studies.zsibok@rkk.hu \\ Cite this article: Zsibók, Z. (2017). Spatial imbalances in the United Kingdom after the Millennium: a \\ focus on the cities. Deturope, 9(3):61-84.
}

\begin{abstract}
During the recovery after the economic crisis, much academic and policy attention was diverted to the role of cities as growth hubs all over Europe and the world. Significant economic disparities are a longstanding problem for the United Kingdom as a whole, which have been growing for decades and are remarkably high among the most developed OECD and EU countries. To investigate recent spatial processes, the methodology of our research relies on comparative spatial data analysis and literature review. Our analyses will cover the issue of a spatially more balanced development based on the "northern powerhouse" initiative which builds upon the collective strength of the cities in the North. Addressing the 'national' problem of regional inequalities, spatial rebalancing is assumed to be inevitable, especially in the light of the new economic and regional challenges posed by the Brexit decision.
\end{abstract}

Keywords: regional inequalities, cities, metropolitan areas, United Kingdom

\section{INTRODUCTION}

Cities are often described as engines of economic growth in political rhetoric, economic policy debates and popular press, and therefore, there is an increased interest in the economic role of the cities (Hildreth and Bailey, 2013). The United Kingdom is a relatively developed nation amongst the member states of the European Union, ${ }^{1}$ but regional inequalities are a long-standing phenomenon: they have been present since the industrial development with swinging intensity (Zsibók, 2017). The development gap seems to steadily widen since the 1980s (Marshall, 1990, Gudgin and Schofield, 1993, Gardiner et al., 2013), particularly, the extent and the trends of spatial disparities are now considered to be a 'national problem' in the United Kingdom, and deserve special policy attention (McCann, 2016). Place-based, local growth oriented policy approaches shifted the focus on the cities to solve this problem (Hildreth and Bailey, 2013).

\footnotetext{
${ }^{1}$ According to EuroStat data, its per capita GDP was around 130 per cent of the EU average between 2000 and 2014, but it deteriorated a lot during and after the financial and economic crisis (from 146 per cent to 127 per cent).
} 
There has long been a debate whether there is a trade-off between spatial disparities and national growth in an economy, that is, whether policies seeking to reduce regional economic inequality hinder national growth or not (Martin, 2008, Dijkstra, 2013). The theoretical bases of the New Economic Geography imply that uneven geographical development may create higher rates of national growth through the spatial agglomeration of economic activities and the increasing returns effects (Gardiner et al. 2013). This approach favours the spatial concentration of investments into the core regions. Although this line of reasoning is deeply present in current policy thinking, several research efforts questioned its actual relevance (Dijkstra, 2013). Martin (2008) emphasises the need for a detailed and intensive research to ascertain whether and to what extent spatial agglomeration increases local and national economic growth. All in all, different courses of economic policy placed different emphasis on promoting a regionally balanced economic growth in the UK. Gardiner et al. (2013) argue that spatially unbalanced development and growth may bias or even compromise national economic policy, which was the case in the UK during and after the economic crisis in the second half of the 2000's. The Brexit process poses further challenges for the national economy through the weakening of economic (trade) linkages with the Continent and losing EU supports, therefore highlights policy attention towards the catching-up of less buoyant regions. $^{2}$

In this paper we intend to examine that to what extent the UK's economy is imbalanced and how the position of the metropolitan areas changed after the Millennium. The empirical analysis will be completed at a fairly aggregated, regional level. In the second section we outline the two main features of the United Kingdom's regional problem, the North-South divide and London's overly dominance. The third section focuses on the empirical findings concerning the cities in the North and the South of the UK and highlights some opportunities for rebalancing the UK's economy. Then, the last section summarises our findings.

\section{The regional problem of the United Kingdom}

Spatial economic imbalance in the UK is a long-standing problem and it appears in several aspects: in addition to spatial disparities, there is a sectoral imbalance, since the UK economy as a whole is over-dependent on financial services, and in certain parts of the nation, employment is largely based on the public sector, and there is also an imbalance in the allocation of power, resources and responsibilities between the centre (Whitehall) and the rest of the country, such as the cities or regions (HM Government, 2010, Hildreth and Bailey,

\footnotetext{
${ }^{2}$ The website of the Regional Studies Association presents rich information content on the regional issues of the Brexit process: http://brexit.regionalstudies.org/.
} 
2013, Gardiner et al. 2013). Two important features of the 'regional problem' are the wellknown North-South divide and the excessive dominance of London and the South East. Over the past few decades there have been a gradual shift in the balance of population and economic activity towards the southern part of mainland Britain (Rowthorn, 2010). Both the differential regional impacts of globalisation processes and the unusual extent of governance centralisation contributed to the phenomenon that McCann (2016) depicts as the UK's interregional decoupling, dislocating and disconnecting. Actually, the UK can be considered to consist of three different economies: London and its hinterland (South East, East of England and South West), Scotland and the rest (McCann, 2016).

\section{The North-South divide}

The UK obviously has a two-speed economy which is prevalent even after the economic crisis (Zsibók, 2017). The concept of the North-South divide is present in current economic policy debates in the UK and it has deep historical roots (Baker and Billinge 2004). Regional disparities in economic and social conditions have been a persistent feature of the UK since the middle of the $19^{\text {th }}$ century (Martin et al 2015). Gardiner et al. (2013) highlights the role of distinctive regional patterns of industrial specialization and that at the end of the $19^{\text {th }}$ century, the northern industrial regions tended to have the most unstable economies and most frequent periods of high unemployment as a consequence of their dependence on export trade. The South has suffered less from the decline of manufacturing and mining employment (the 'old economy') and it has gained a much greater share of the new jobs in some dynamic areas, such as financial and business services (the 'new economy') (Rowthorn, 2010, Gardiner et al., 2013). Proximity to the sources of raw materials is no longer a crucial locational factor for industry; instead, the immense pool of creativity and talent are the ones that matter the most (Osborne, 2014).

To characterize the UK economy with the North-South divide is, certainly, a simplification, but in broad terms, the divergence between the two major areas is undeniable (Martin et al. 2015). Gardiner et al. (2013) presents that in some cases, the existence of a North-South divide is questioned, since local areas of economic depression and deprivation can be found in the South, while areas of growth and prosperity can be found in the North. Of course, the picture is more complex at the local level than it is at the regional scale, even London has some areas of high unemployment and poverty (Hackney and Tower Hamlets, just to mention two of them). However, the basic argument behind the North-South divide is that the South as a whole has been more dynamic than the North in recent decades. As a 
consequence, employment and incomes in the North are boosted by fiscal transfers from the South which makes the North especially vulnerable to fiscal austerity measures, whereas the South is even more vulnerable to higher taxes (Rowthorn, 2010).

According to the classification of Gardiner et al. (2013) the North consists of the following regions: West Midlands, Wales, Yorkshire and the Humber, North West, North East and Scotland, while the South consists of London, South East, South West, East of England and East Midlands (see Fig 1). Geographically, the dividing line is usually drawn between the Wash and the Severn Estuary. The concentration of the economic potential in the South East is constantly increasing, which is illustrated by the fact that Gudgin and Schofield (1993) classified the whole Midlands in the 'South' and considered that the economic problems of the West Midlands had been only temporary. As the UK's economy has "gone South" (McCann 2016 p. xxvii), West Midlands have lost its position of being part of the prosperous South, and, in some aspects, the East Midlands' situation is also ambiguous now.

Figure 1 The regions of the "North" and the "South" in the United Kingdom

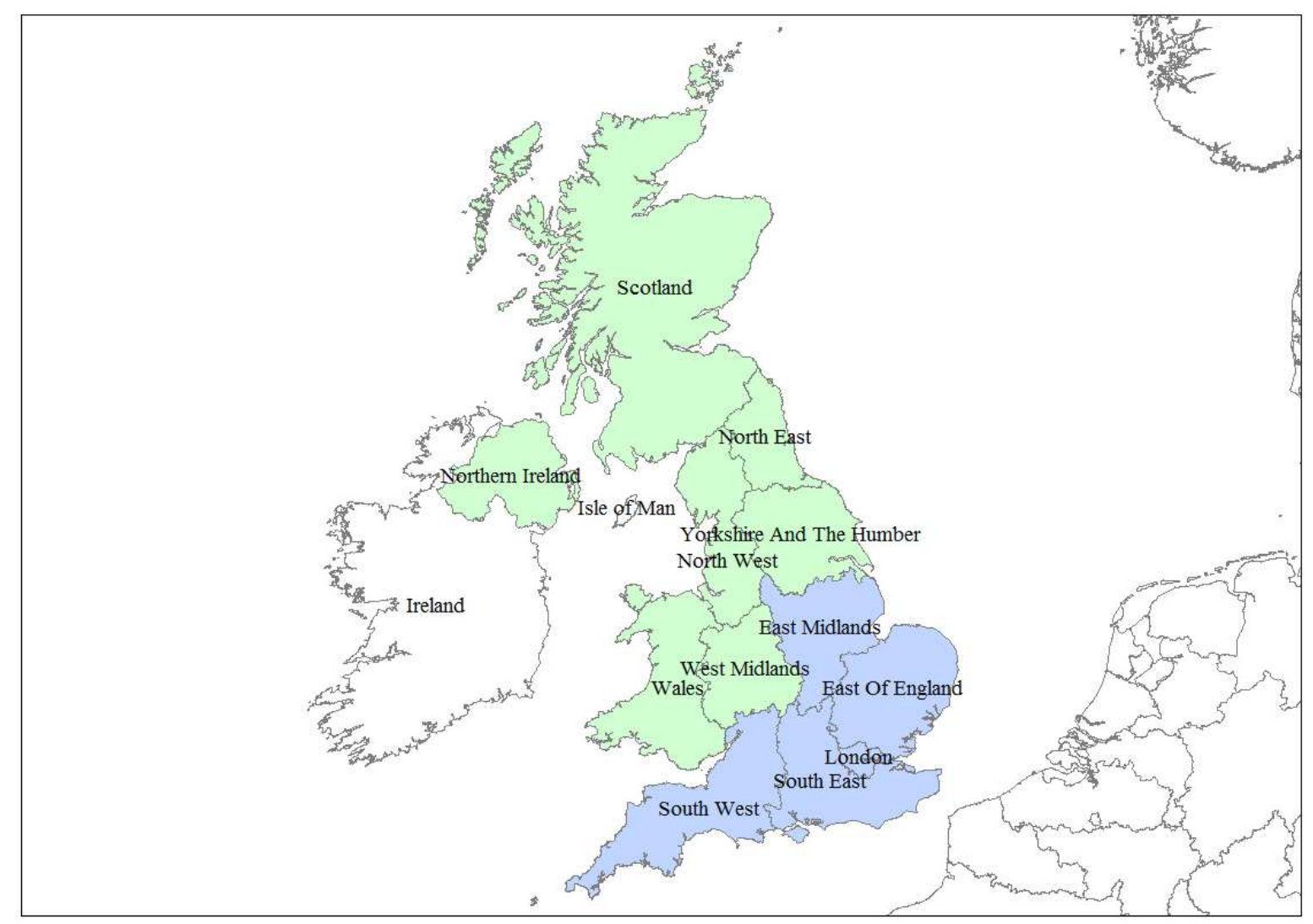

Source: Author's elaboration based on Gardiner et al. (2013)

In the following paragraphs, we investigate the North-South divide through some basic economic indicators, the per capita GDP series, the employment and the unemployment data 
provided by EuroStat. Table 1 presents the NUTS 1 level per capita GDP relative to the national average, employment rates and unemployment rates after the Millennium.

Table 1 Average per capita GDP, employment rates and unemployment rates between 2000 and 2015 in the United Kingdom at the NUTS 1 level

\begin{tabular}{llrrr}
\hline $\begin{array}{c}\text { NUTS } \\
\text { Code }\end{array}$ & \multicolumn{1}{c}{ NUTS Name } & $\begin{array}{r}\text { Per capita } \\
\text { GDP (UK }=\end{array}$ & $\begin{array}{c}\text { Employment } \\
\text { rate, \% }\end{array}$ & $\begin{array}{c}\text { Unemployment } \\
\text { rate, \% }\end{array}$ \\
\hline UKC & North East & 73.58 & 66.18 & 7.96 \\
UKD & North West & 85.16 & 69.07 & 6.26 \\
UKE & Yorkshire-Humber & 82.09 & 69.73 & 6.59 \\
UKF & East Midlands & 82.38 & 72.23 & 5.63 \\
UKG & West Midlands & 82.91 & 69.45 & 6.82 \\
UKH & East of England & 94.93 & 74.71 & 4.84 \\
UKI & London & 163.35 & 68.48 & 7.51 \\
UKJ & South East & 108.30 & 75.58 & 4.56 \\
UKK & South West & 89.92 & 74.70 & 4.48 \\
UKL & Wales & 70.85 & 67.67 & 6.32 \\
UKM & Scotland & 92.05 & 71.16 & 6.31 \\
UKN & Northern Ireland & 78.93 & 65.50 & 5.85 \\
\hline UK & United Kingdom & 100.00 & 71.03 & 5.99 \\
\hline
\end{tabular}

* Per capita GDP data are available between 2000 and 2014

Source: Author's elaboration based on EuroStat data.

In most of the regions, the evolution of the regional per capita GDP was more or less stable in time over the period between 2000 and 2014 in relation to the national average, but there are also some exceptions. London constantly advanced (from 163 to 171 per cent) ${ }^{3}$, and also, the North East, the North West and Scotland improved their position with around 2 to 3 percentage points. ${ }^{4}$ The largest deterioration was observed in the West Midlands (from 87 to 80.5 per cent), in Northern Ireland (from 80 to 75 per cent) and in the East of England (from 97 to 92 per cent). As Martin (2015) states, the long boom between the early-1990s and 2007 reinforced regional inequalities. And so did the financial and economic crisis after 2008. In the UK, spatially unbalanced growth is recognized politically both as having contributed to the economic crisis and also as a hindrance to future economic stability (Martin 2015). The coefficient of variation regarding the relative per capita GDP at the NUTS 1 level is around 30 per cent and around 70 per cent at the NUTS 2 level, while it has an increasing trend, implying a cross-sectional divergence.

As expected, the picture is more mixed at a more disaggregated level regarding the average per capita GDP between 2000 and 2014. At an average, these values range between 62 per

\footnotetext{
${ }^{3}$ Nevertheless, there have been significant internal inequalities at the NUTS 2 level.

${ }^{4}$ Especially, North Eastern Scotland improved a lot from 117.5 per cent in 2000 to 150 per cent in 2014, while the other two NUTS 2 regions of Scotland nearly stagnated.
} 
cent (West Wales and the Valleys) and 464 per cent (Inner London - West) ${ }^{5}$ of the national average. Out of the 40 regions at the NUTS 2 level, only ten regions have a per capita GDP above the national average, and two of them can be found in the 'North' (North Eastern Scotland, 133 per cent and Cheshire, 111 per cent).

Employment data firmly supports the North-South region classification of Gardiner et al. (2013) depicted above. Typically, the South East, the South West, the East of England, East Midlands and Scotland are above the national average (71 per cent) employment rate, while London is, at an average, significantly below this level (Fig. 2). The economic and financial crisis resulted in a 2 percentage points' drop in the average employment rate by 2011, however, the indicator recovered to nearly 73 per cent by 2015 and it is permanently increasing since 2012. The relative position of the regions at the NUTS 1 level has not changed much after the crisis, excepting Scotland, which improved a lot from 68.5 per cent in 2000 to 73.4 per cent in 2015 (Zsibók, 2017) ${ }^{6}$.

Figure 2 The evolution of the employment rates between 2000 and 2015 in the United Kingdom

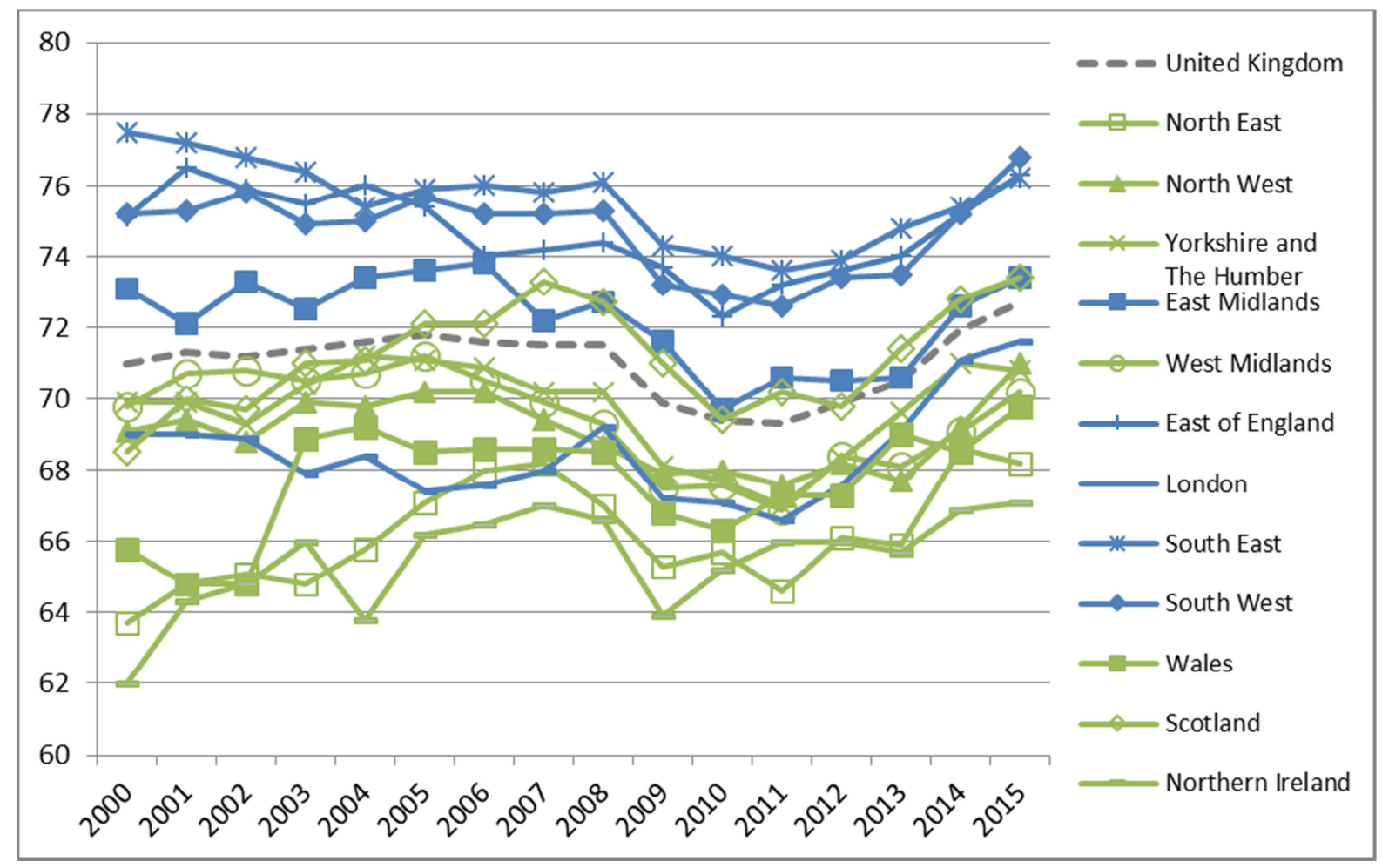

Source: Author's elaboration based on EuroStat data.

\footnotetext{
${ }^{5}$ The average value for Inner London is 316.26 per cent and computed as the average of Inner London West (=464.22 per cent) and Inner London East ( $=168.29$ per cent). The average value of Outer London is 92.69 per cent which is computed as the average of Outer London East and North East $(=75.00$ per cent), Outer London South ( $=92.87$ per cent) and Outer London West and North West ( $=110.19$ per cent).

${ }^{6}$ The highest employment rate was measured in North Eastern Scotland (77.2 per cent) and in the Highlands and Islands region (74.6 per cent), while Eastern Scotland (72.5 per cent) and South Western Scotland (67.9 per cent) have lower rates.
} 
Concerning unemployment rates, spatial differences have been relatively high in the regions of the United Kingdom after the Millennium, though they decreased until the economic crisis, and have increased again during the recovery phase (see Table 2). The worst performing NUTS 2 regions are the North East, London, West Midlands and Yorkshire and the Humber, while the lowest average unemployment rates were measured in the South West and South East. During the economic crisis, the regions of both the South and the North were hit by the job losses in the industry. In broad terms, the South was able to restore its labour market relatively soon, but since incomes and employment in the North are largely dependent on the public sector, the austerity measures during the recovery hindered the catching-up in these regions. According to Rowthorn (2010), London's labour market is characterised by a large surplus of unqualified workers which reflect the consequences of its industrial past and international migration. Although the growth of the 'new economy' resulted in extra demand for labour in certain sectors, it was not able to counterbalance the huge loss of manufacturing and related jobs (Rowthorn, 2010). This means that London's economy is not exempt from structural problems which contribute to a continued internal social polarisation.

Table 2 Unemployment rates in the United Kingdom between 2001 and 2015 at the NUTS 1 level

\begin{tabular}{lrrrrrrrrr}
\hline NUTS name & 2001 & 2003 & 2005 & 2007 & 2009 & 2011 & 2013 & 2015 \\
\hline London & 5.8 & 6.6 & 7.0 & 6.8 & 9.0 & 9.8 & 8.6 & 6.2 \\
South East & 2.9 & 3.7 & 3.8 & 4.4 & 5.8 & 6.0 & 5.8 & 4.0 \\
South West & 3.5 & 3.6 & 3.6 & 3.8 & 6.1 & 6.3 & 6.1 & 3.9 \\
East of England & 3.5 & 3.8 & 3.9 & 4.6 & 6.2 & 6.6 & 6 & 4.2 \\
East Midlands & 4.8 & 3.9 & 4.3 & 5.2 & 7.1 & 7.9 & 7.3 & 4.6 \\
\hline West Midlands & 4.9 & 5.5 & 4.7 & 6.2 & 9.6 & 9.0 & 9.1 & 5.8 \\
North East & 7.4 & 6.5 & 6.1 & 6.1 & 9.1 & 10.7 & 10 & 8.0 \\
North West & 5.0 & 4.7 & 4.6 & 5.8 & 8.3 & 8.4 & 8 & 5.4 \\
Yorkshire-Humber & 4.7 & 5.3 & 4.7 & 5.5 & 8.5 & 9.3 & 8.7 & 6.2 \\
Wales & 5.5 & 4.4 & 4.5 & 5.2 & 8.0 & 8.6 & 7.6 & 5.9 \\
Scotland & 5.7 & 5.3 & 5.3 & 4.7 & 6.9 & 8.0 & 7.2 & 5.7 \\
Northern Ireland & 6.1 & 5.2 & 4.7 & 3.8 & 6.4 & 7.2 & 7.5 & 6.1 \\
\hline United Kingdom & 4.7 & 4.8 & 4.8 & 5.3 & 7.5 & 8.0 & 7.5 & 5.3 \\
\hline
\end{tabular}

Source: Author's elaboration based on EuroStat data.

The most notable feature of the North-South divide is the productivity gap. During the recovery after the financial and economic crisis, the UK were not able to solve the productivity puzzle, that is, the persistently stagnant productivity performance. Many of the UK cities are less productive than their European counterparts (Bessis, 2016). According to The Northern Powerhouse Independent Economic Review (SQW, 2016), the performance gap 
is mainly driven by the skills gap, which influences both productivity and the employment rate. The widening of the gap between North and South can be attributable to the outmigration of skilled workforce from northern areas in search of better job opportunities. The review considers other causes behind the performance gap such as underinvestment, low enterprise rates, a lack of agglomeration and poor connectivity. In contrast to the expectations, the review states that the North's sectoral mix accounts for very little of the productivity gap. Also unexpected is the fact that in the Northern regions, even cities cannot realize productivity premiums (McCann, 2016).

\section{The 'London problem'}

London's dominance over the rest of the country, in other words, the issue of 'London versus the rest' attracts much attention in recent public discourses. ${ }^{7}$ The 'London problem' highlights the question that how much the other parts of the UK benefits from the prosperity of the capital city, and whether the concentration of increasing public and private resources in London have any beneficial spillover effect outside the Southeastern corner of the country vis$\grave{a}$-vis a more even allocation of resources (see the contrasting views in, for example, Overman, 2013 and McCann, 2016).

Table 3 Population, employment and GDP of the NUTS 1 regions in the United Kingdom, 2014

\begin{tabular}{|c|c|c|c|c|c|c|c|c|c|}
\hline & \multicolumn{3}{|c|}{ Population } & \multicolumn{3}{|c|}{ Employment } & \multicolumn{3}{|c|}{ GDP } \\
\hline & $\begin{array}{c}1000 \\
\text { people }\end{array}$ & Share & $\begin{array}{l}\begin{array}{l}\text { Yearly } \\
\text { growth } \\
\text { rate, } \\
2000-14\end{array} \\
\end{array}$ & $\begin{array}{c}1000 \\
\text { people }\end{array}$ & Share & $\begin{array}{l}\begin{array}{l}\text { Yearly } \\
\text { growth } \\
\text { rate, } \\
2000-14\end{array} \\
\end{array}$ & $\begin{array}{c}\text { Million } \\
\text { euros }\end{array}$ & Share & $\begin{array}{c}\text { Yearly } \\
\text { growth } \\
\text { rate, } \\
2000-14\end{array}$ \\
\hline North East & 2614.8 & $4.06 \%$ & $0.19 \%$ & 1143.3 & $3.87 \%$ & $0.67 \%$ & 66700 & $3.00 \%$ & $1.75 \%$ \\
\hline $\begin{array}{l}\text { North West } \\
\text { Yorkshire- }\end{array}$ & 7120.4 & $11.06 \%$ & $0.36 \%$ & 3143.8 & $10.64 \%$ & $0.37 \%$ & 209557 & $9.43 \%$ & $1.58 \%$ \\
\hline Humber & 5356.7 & $8.32 \%$ & $0.55 \%$ & 2408.7 & $8.15 \%$ & $0.62 \%$ & 148869 & $6.70 \%$ & $1.36 \%$ \\
\hline East Midlands & 4614.0 & $7.17 \%$ & $0.74 \%$ & 2132.9 & $7.22 \%$ & $0.60 \%$ & 133084 & $5.99 \%$ & $1.35 \%$ \\
\hline West Midlands & 5691.3 & $8.84 \%$ & $0.55 \%$ & 2478.4 & $8.38 \%$ & $0.40 \%$ & 160458 & $7.22 \%$ & $0.87 \%$ \\
\hline East of England & 5981.7 & $9.30 \%$ & $0.79 \%$ & 2819.3 & $9.54 \%$ & $0.68 \%$ & 194081 & $8.73 \%$ & $1.06 \%$ \\
\hline London & 8477.3 & $13.17 \%$ & $1.18 \%$ & 4157.1 & $14.06 \%$ & $1.54 \%$ & 509402 & $22.91 \%$ & $1.79 \%$ \\
\hline South East & 8828.3 & $13.72 \%$ & $0.73 \%$ & 4170.2 & $14.11 \%$ & $0.43 \%$ & 335161 & $15.07 \%$ & $1.29 \%$ \\
\hline South West & 5396.7 & $8.39 \%$ & $0.69 \%$ & 2488.4 & $8.42 \%$ & $0.60 \%$ & 169288 & $7.61 \%$ & $1.48 \%$ \\
\hline Wales & 3095.1 & $4.81 \%$ & $0.46 \%$ & 1320.3 & $4.47 \%$ & $0.65 \%$ & 75976 & $3.42 \%$ & $1.42 \%$ \\
\hline Scotland & 5337.5 & $8.29 \%$ & $0.37 \%$ & 2509.7 & $8.49 \%$ & $0.75 \%$ & 172744 & $7.77 \%$ & $1.67 \%$ \\
\hline Northern Ireland & 1837.3 & $2.86 \%$ & $0.64 \%$ & 787.6 & $2.66 \%$ & $1.27 \%$ & 48078 & $2.16 \%$ & $0.91 \%$ \\
\hline United Kingdom & 64351.2 & $100.00 \%$ & $0.65 \%$ & 29559.7 & $100.00 \%$ & $0.70 \%$ & 2223398 & $100.00 \%$ & $1.43 \%$ \\
\hline
\end{tabular}

\footnotetext{
${ }^{7}$ See, for example the „Mind the gap” BBC television programme broadcast in 2014.
} 
After the recession, London and the South East hold more than a quarter of the population and the employment, and 38 per cent of the GDP of the whole UK (Table 3). Back in the middle of the previous century, the Barlow Report (Report of the Barlow Commission on the Distribution of the Industrial Population, 1940) raised concerns that the concentration of economic activity and growth in London and the South East could lead to problems of congestion, urban sprawl and inflation. The report proposed a recommendation which would actively intervene in the spatial allocation of economic potential, investments and employment between the different parts of the nation. The Commission argued that the control of London's growth was necessary to reduce the disparities between North and South, and that measures should be taken to (re)locate fast growing industries to the slow growing regions. Contesting this position, Martin (2015) argues that there is not some fixed amount of economic growth or activity that has to be distributed across the national economy through holding back prosperous areas in order to promote activity in the less prosperous cities and regions. Actually, the major shortcomings arise in the governance system (see also McCann, 2016). In order to ensure that the less prosperous areas are able to realize their full economic potential, proper and fair access to the public and private resources are needed for them (Martin, 2015). However, the cities and regions outside London feel that the national policy is London-centric and ignores their needs and conditions (Wilcox et al. 2014). Some kind of relocation ideas appeared at higher governmental levels, though, which view public sector employment as a device for promoting economic development in lagging regions: the review of Smith (2010) suggests that there is considerable scope for rebalancing government activity between London and the rest of the country through the relocation of civil servant jobs. According to the review, a robust and self-sustaining relocation programme should produce a measurable and permanent shift of activity from London. It is intended to "give significant cost savings to the taxpayer, contribute to the economic vibrancy of the rest of the UK and through links with the private sector, help create centres of excellence that help build clusters of international competitiveness." (p5). Of course, such programme would presume a strong, persistent government commitment.

The excessive concentration of economic power in the capital city has, among others, two general consequences that co-exist. The economy of London and its hinterland generates demand for goods and services in the rest of the UK, and London is a major contributor to the taxes which help fund welfare payments and public spending across the whole nation (City of London Corporation, 2011, Martin, 2015). At the same time, London's economy seems to be 
rather detached from the economic processes elsewhere in the country in terms of its level of prosperity, economic growth, global orientation and cyclical behaviour (Martin, 2015). The economy of London and the South East proved highly resilient during and after the economic crisis (Bell and Eiser, 2015), and recently, this region leads the recovery while the northern regions are left behind. The recent knowledge-based economic environment prefers the spatial clustering of businesses. Being a global economic hub, London undeniably benefits much from the self-reinforcing agglomeration economies, and, as a consequence, it sucks businesses, investments and human capital from the rest of the country (as well as Europe and the world), referred to as being a 'black hole' (Sturgeon 2014). As a result, the permanent transfer of economic potential from the slow-growing regions towards the most prosperous areas damages the economic power of the source regions, leave labour and capital resources underutilized, and, therefore, is inefficient for the nation as a whole (see Rowthorn, 2010, Gardiner et al., 2011). At the same time, congestion and high property prices pose local challenges in London, but have an effect on the whole country, as well, through for example, location and internal migration decisions (see Fothergill and Houston, 2016 for a comparison of the advantages of the cities versus the non-city areas).

The excessive dominance of London over the rest of the UK is certainly not an outcome of pure market forces. The UK is characterised by one of the most centralized national political and financial systems amongst the OECD countries, and London receives huge amounts of public expenditures on infrastructure, transport ${ }^{8}$, education, health services and cultural institutions. These kinds of public investments undeniably prioritise the capital city on the grounds of efficiency arguments. Gordon (2016) finds that the financial sector proved both the most resilient in the economic downturn and the most dynamic in the upturn. He explains this process partly with the fact that London's financial sector received massive state support for bank bail-out and quantitative easing. Martin (2015) highlights that the forces behind spatial economic imbalance in the UK have become institutionalized, embedded in the national political economy, spatially concentrated in and controlled from London. This means that the UK's political, administrative and governance system is far from being neutral from an economic geographical point of view.

\footnotetext{
${ }^{8}$ The most notable recent transport investment is the Crossrail railway construction programme connecting the east and the west parts of London which is underway, and expected to open in December, 2018, costing around 15 billion pounds.
} 


\section{Cities in the focus of spatial rebalancing in the UK}

In the UK, around three quarters of the population live in cities and their surrounding areas. HM Treasury (2015) describes the role of cities in the UK's economy as they attract high value firms and skilled workers, help to boost the productivity of those that locate there, as well as cities provide deep markets for labour, vibrant competition between firms, and enable the rapid diffusion of new ideas.

In response to the financial and economic crisis, the UK government assigned key importance to the need to spatially rebalance the economy, to reduce its dependence on London and the South East by powering up northern cities (Martin, 2015). There is currently much interest in this issue not only at the central government level, but also within the major cities, regions and nations of the country (Martin et al., 2015). Important policy initiatives appeared such as Local Enterprise Partnerships, Enterprise Zones, city deals as steps towards the devolution of powers, northern high speed rail developments (HS2 and HS3) ${ }^{9}$, the Northern Powerhouse initiative, the Regional Growth Fund (launched in 2010, operating in six rounds between 2011 and 2017) and the Midlands Engine Strategy (HM Government, 2017) but their actual effectiveness is questionable (Hildreth and Bailey, 2013). Martin (2015) is quite pessimistic stating that at best the impact of such policies is expected to be small, since such measures remain piecemeal, 'add-on' and marginal to the basic structures and workings of the UK's national system of fiscal, monetary and economic management, which favours London and its environs.

\section{"Powering up" northern cities}

In the UK, city size is not directly related to better productivity performance, rather, productivity benefits appear in the Southern regions, even in smaller settlements (McCann, 2016). The weaker performance of many of the northern cities has attracted government attention in the past few years. The 'Northern Powerhouse' initiative was introduced by Chancellor George Osborne in 2014, stating that the cities of the North (Manchester, Liverpool, Leeds and Newcastle) are individually strong, but collectively not strong enough. With fiscal powers, a collection of northern cities, sufficiently close to each other would be able to rebalance the economy (Osborne, 2014). Northern cities are going through a modern

\footnotetext{
${ }^{9}$ High Speed Rail 2 is planned to be a Y-shaped, south-west railway line to connect London, Birmingham, Manchester, Sheffield and Leeds. High Speed Rail 3 or Northern Powerhouse Rail is a proposed east-west railway line crossing the Pennine, which is designed to connect Liverpool, Manchester, Leeds, Sheffield and Hull. Under a „North First” policy approach, the HS3 development should take priority over HS2 and Crossrail in order to best serve the spatial rebalancing after the Brexit decision (see IPPR urges government to prioritise HS3 link).
} 
transformation through physical renewal, cultural revitalisation, health and education investments and the improvement of the quality of life (Rowthorn, 2010, Osborne, 2014, Fothergill and Houston, 2016).

Osborne is firm on the view that the excessive and increasing dominance of London is not healthy for the UK economy. The northern powerhouse is expected to be able to grow up with the South East, however, the growth of London is not hindered in any way (Martin 2015). Through increasing jobs and incomes for the people living in the North, it would be possible to redress the North-South divide and increase national productivity. In the spirit of the northern powerhouse, it is essential for the government to be committed to focus investment in key Northern city regions as growth hubs. The main elements of the programme would be the development of modern transport connections ${ }^{10}$, supporting science, universities, creative clusters, and giving the cities local power and control (elected mayors) (Osborne, 2014). The suggestions laid down by Osborne have appeared in a report of the Treasury (HM Treasury, 2015) demonstrating the commitment of the government towards spatial rebalancing.

The Cities and Local Government Devolution Act 2016 opens the way to have elected mayors for the combined authority areas. Established by the Parliament, combined authority areas $^{11}$ are partnerships of two or more councils to collaborate and take collective decisions which can take advantage of powers and resources devolved to them from national government. In the middle of 2017, there are nine combined authorities:

- Greater Manchester Combined Authority

- Liverpool City Region

- North East Combined Authority

- Sheffield City Region

- Tees Valley Combined Authority

- West Midlands Combined Authority

- West Yorkshire Combined Authority

- Cambridgeshire and Peterborough Combined Authority

- West of England Combined Authority.

In addition, there are some more areas that are considering a combined authority and some proposals have failed. However, Martin (2015) emphasises that fiscal devolution is a

\footnotetext{
${ }^{10}$ A radical transport plan would ensure that ,travelling between cities feels like travelling within one big city" (Osborne, 2014).

${ }_{11}$ Information about combined authority areas are retrieved from the Local Government Association: http://www.local.gov.uk/topics/devolution.
} 
necessary condition, but not a sufficient one for spatial balance, since it could favour the very largest cities and penalize less-prosperous cities, and it not necessarily translates into effective and successful local economic growth and development.

\section{Metropolitan areas}

In this section we extend our previous empirical analyses, and focus on the metropolitan areas. The presented data are provided by the OECD urban data set which defines 'urban' according to contiguous development patterns and commuting behaviour. According to the OECD methodology, metropolitan urban areas are larger cities and their commuting zones with a total of over 500 thousand inhabitants (McCann, 2016).

Table 4 Shares of the metropolitan areas in the total population, GDP, labour force, employment and unemployment of the UK, 2014 (\%).

\begin{tabular}{lrrrrr}
\hline & Population & GDP & Labour force & Employment & Unemployment \\
\hline London & 19.28 & 28.39 & 19.95 & 19.88 & 21.14 \\
Birmingham & 3.04 & 2.68 & 2.76 & 2.67 & 4.16 \\
Leeds & 1.86 & 1.88 & 1.83 & 1.80 & 2.28 \\
Bradford & 0.90 & 0.60 & 0.78 & 0.77 & 1.06 \\
Liverpool & 1.48 & 1.25 & 1.44 & 1.38 & 2.26 \\
Manchester & 3.01 & 3.01 & 2.90 & 2.86 & 3.47 \\
Cardiff & 1.03 & 0.88 & 1.00 & 0.98 & 1.20 \\
Sheffield & 1.43 & 1.06 & 1.39 & 1.35 & 2.02 \\
Bristol & 1.30 & 1.47 & 1.34 & 1.34 & 1.39 \\
Newcastle & 1.68 & 1.27 & 1.63 & 1.60 & 2.12 \\
Leicester & 1.08 & 0.90 & 1.03 & 1.03 & 1.02 \\
Portsmouth & 0.92 & 0.97 & 0.94 & 0.96 & 0.66 \\
Nottingham & 1.34 & 1.12 & 1.29 & 1.27 & 1.63 \\
Glasgow & 1.50 & 1.62 & 1.44 & 1.41 & 2.02 \\
Edinburgh & 1.19 & 1.48 & 1.20 & 1.22 & 0.91 \\
\hline : Author's elaboration based on OECD data. & & &
\end{tabular}

Source: Author's elaboration based on OECD data.

The data presented above reflects the fact that the economic space of the UK is "spiky" (see Hildreth and Bailey, 2013), that is, the only significant "spike" is London, whereas the other parts of the country are relatively flat. Birmingham and Manchester emerge as secondtier cities, but they are even together too small to counterweight the capital. Furthermore, this holds if we sum up all the other metropolitan areas (Table 4).

During the recovery after the financial and economic crisis, the potential of the UK's "biggest cities as genuine drivers of economic growth" gained particular interest (HM Government, 2010). Besides the Northern Powerhouse approach which concentrates on the Northern 'mega-city-region', the City Growth Commission (2014) take a more polycentric 
view, and identify 15 metropolitan areas ${ }^{12}$ around the UK as candidate economic hubs of major city regions. The report emphasises that for the country it is better not to rely only on a few growth hubs, but cities all across the UK need to be empowered to unleash their creativity and innovation potential, improve their connectivity and boost their productivity. The central elements of the Commission's recommendations are a more decentralised political system that creates fiscal and financial flexibility for the city-regions, as well as supply-side policies that enhance connectivity, housing, skills and innovation at the scale of city-regions.

Figure 3 indicates that the highest population growth rates tend to appear in the smaller, Southern cities (Milton Keynes, Peterborough, Swindon and Cambridge), while many of the largest Northern cities tend to have smaller population growth after the Millennium. The fastest-growing Northern cities include Manchester, Nottingham, York, Leicester and Cardiff. Close to or below zero population growth was reported in Blackpool, Sunderland, Middlesbrough and Dundee.

Figure 3 Population and population growth in the largest 50 cities of the North and the South (without London)

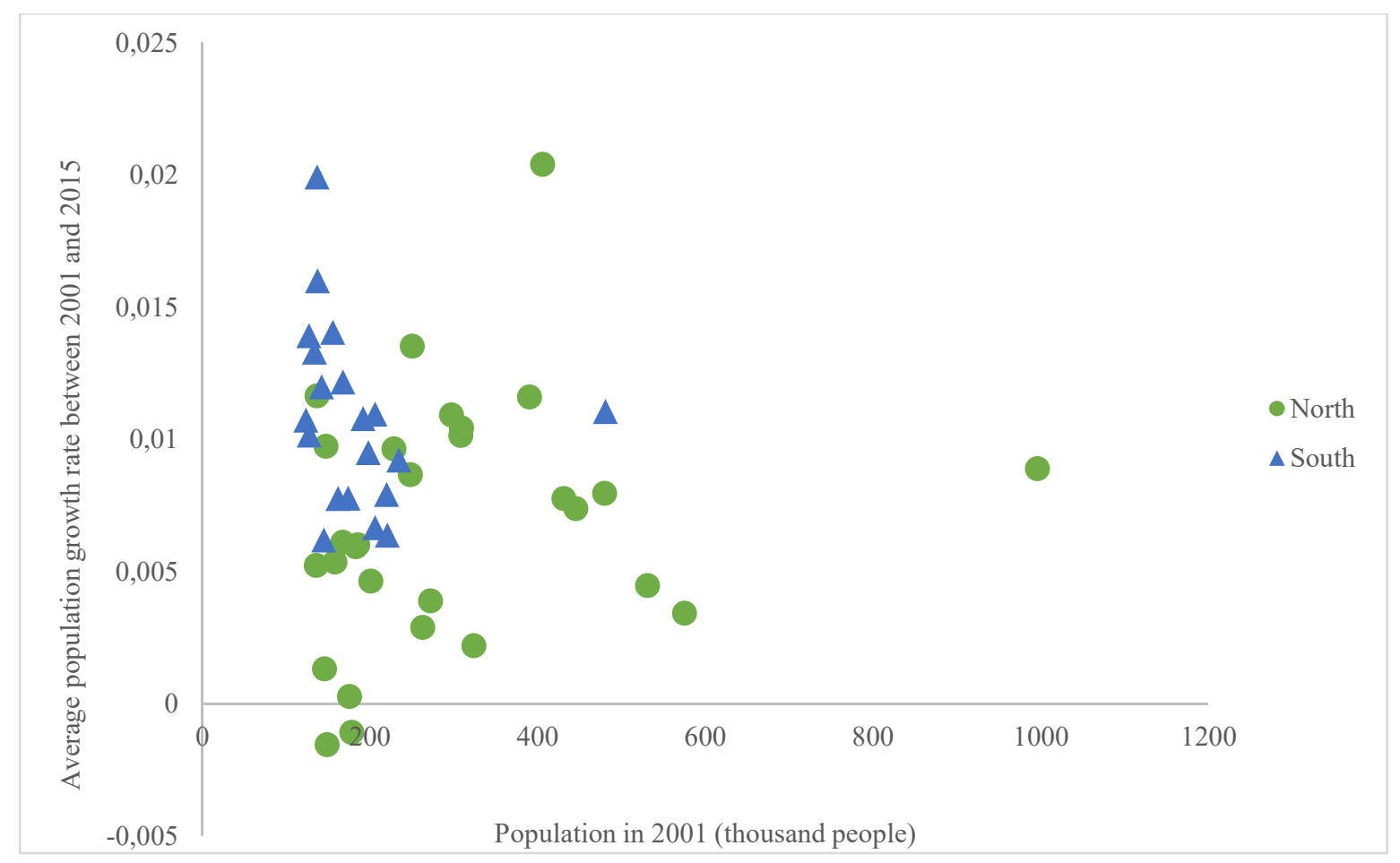

Source: Author's elaboration based on www.citypopulation.de data (UK National Statistics, General Records of Scotland, The Northern Ireland Statistics and Research Agency).

\footnotetext{
${ }^{12}$ London Metro, Greater Manchester Metro, West Midlands Metro, West Yorkshire Metro, Glasgow Metro, Merseyside Metro, Tyne and Wear Metro, South Yorkshire Metro, East Midlands Metro, South Hampshire Metro, Edinburgh Metro, Cardiff Capital Region Metro, Bristol Metro, Belfast Metro and Leicester Metro.
} 
The most well-known feature concerning city size is the so-called Zipf's Law, or rank-size rule (Zipf, 1949). This rule states that the population of a city is inversely proportional to its rank. According to this, the second largest city in a country would have half the population of the biggest city; the third largest city would have one third the population, and so on (see Fig. 4).

Figure 4 Zipf's law in the United Kingdom: the relationship between city size and rank, 2014

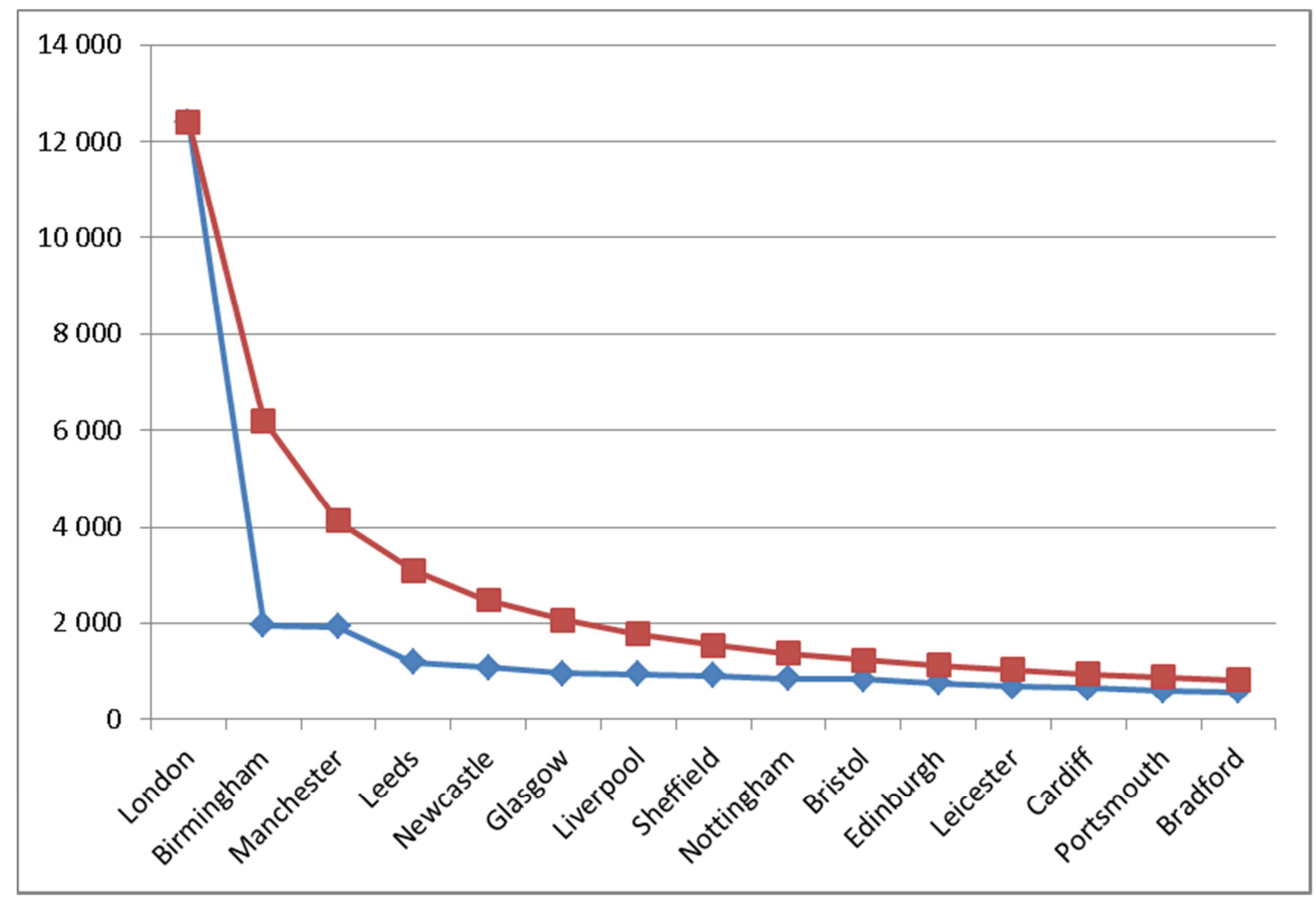

Note: Blue: actual size; Red: city size predicted by Zipf's Law Source: Author's calculations based on OECD data.

As indicated by Figure 4, the city size distribution of the UK not corresponds to the Zipf's Law: the second and the third largest cities would not, even combined, reach the half of London's population. Is London too big for the country or the second-tier cities prove too small? It would be a challenge to disentangle which aspect is the truth: should the growth of the global capital city be constrained? It is, unfortunately, an ambiguous question, furthermore, the empirical regularities expressed in Zipf's Law cannot hold strictly, while its theoretical underpinnings are not researched extensively (see McCann, 2016). In general, London is indeed too big for the UK, but not too big in comparison to its global competitors. The underlying question is that whether a more balanced city-size distribution within the UK would improve or deteriorate the overall competitiveness of the country. In international 
comparison, the UK's second-tier cities prove even relatively large amongst several OECD countries (McCann, 2016). It is also visible on Figure 4 that the actual city size distribution corresponds better to the law in the case of smaller metropolitan areas. The rank-size rule largely holds across all of the UK's smaller towns and settlements with populations of over 5000 people (McCann, 2016), or below the top 25 cities (Overman, 2013). Since the secondtier cities are located relatively close to each other in northern England, their large-scale growth is constrained, and urban planning restrictions sometimes have a similar effect (Overman, 2013) ${ }^{13}$. The current UK city size patterns are attributable to deep and longstanding historical roots, as well as the effects of modern globalisation, and cannot be regarded a primary result of the post-2004 EU immigration from Eastern Europe (McCann, 2016). A plausible way for enhancing national performance would be a flatter but more spread-out distribution of economic growth which relies on the potential of various types of areas, from city centres to rural places, all over the country.

To what extent can the recovery of the growth potential rely on the large cities in the UK? According to Martin et al. (2016), the growth paths of the cities are divergent, since the broad geographical pattern of city growth is that northern cities are growing more slowly than most southern ones, and a number of northern cities have shrunk in employment terms after the 1980s. Contradicting the expectations, most of Britain's principal cities have lagged behind smaller cities, especially behind those in the South. The majority of the so-called 'Core Cities ${ }^{14}$ (many located in the North) have not kept pace with the national growth rate in employment or output (Fig. 5 and Fig. 6). The differences can be explained by the fact that not all cities were able to shift their industrial structure from manufacturing and production towards fast-growing knowledge intensive industries (Martin et al., 2016). Cities in the North have small shares of business services jobs, low levels of patent activity and large numbers of residents with few or no formal qualifications, which means that these cities struggle to attract high-skilled investments (Bessis, 2016). After the Millennium, the cities which grew faster

\footnotetext{
13 McCann (2016) counters this latter view by stating that UK city-size distributions have always been characterised by second tier cities which are 'too small' relative to London, even in periods without land-use planning restrictions and greenbelt policies. Moreover, restrictions have been relatively more biting in London and the southern cities than in cities in other regions of the UK.

${ }^{14}$ The Core Cities Group was formed in 1995 as a partnership of eight city councils, with the aim of promoting the role of the participating cities in creating a stronger, fairer economy and society. 'Core Cities' are Birmingham, Bristol, Leeds, Liverpool, Manchester, Newcastle, Nottingham and Sheffield in England, Cardiff in Wales and Glasgow in Scotland (https://www.corecities.com/cities).
} 
than the national performance in terms of per capita GDP were London, Edinburgh, Bristol, Glasgow, Portsmouth, Leeds and Manchester.

Figure 5 Differential growth of GDP and per capita GDP differential compared to the national average in the main metropolitan areas of the United Kingdom

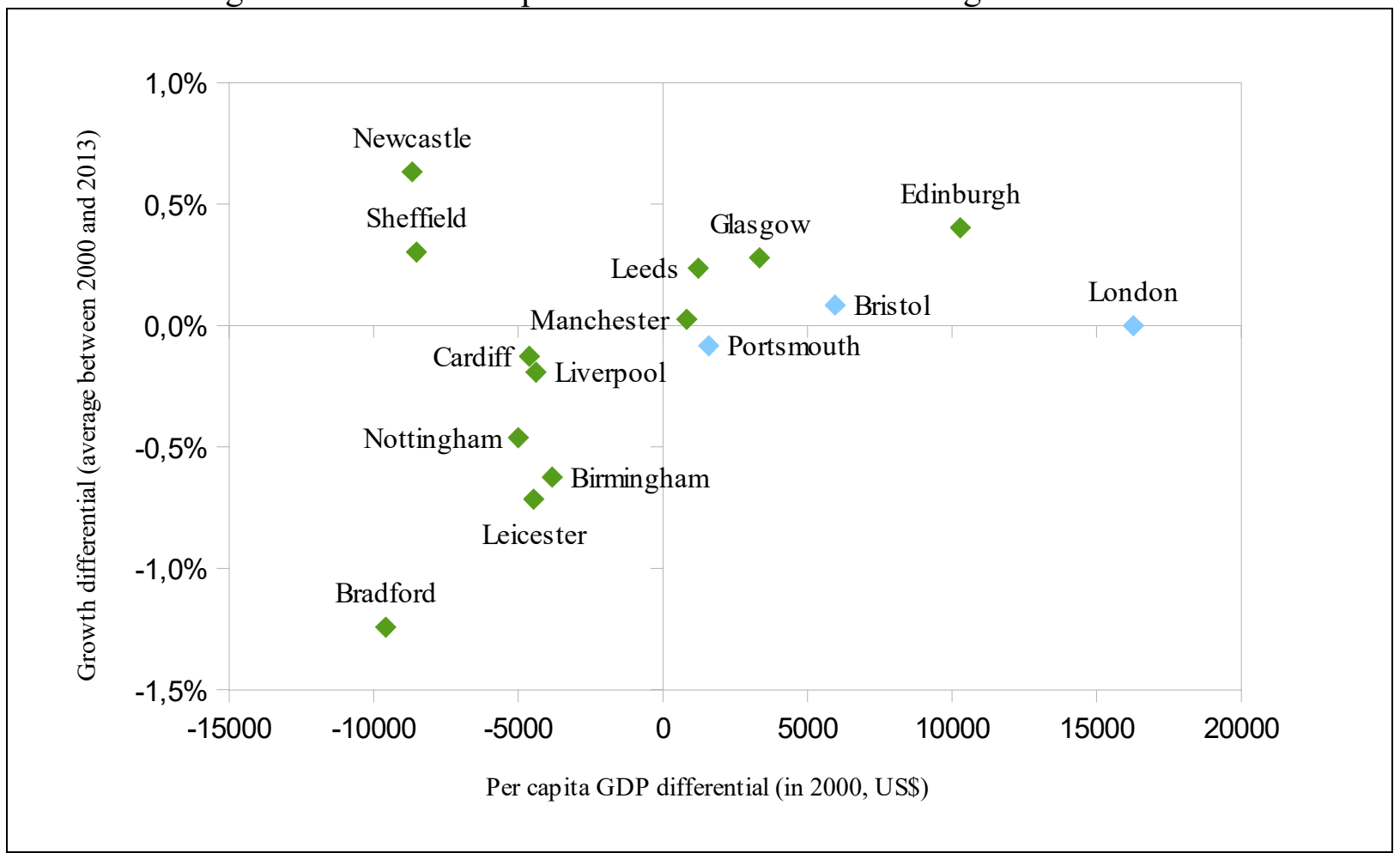

Note: Northern metropolitan areas: green colour, Southern metropolitan areas: blue colour. Zero values represent national average.

Source: Author's elaboration based on OECD data.

In terms of employment, only London was able to grow faster than the national average both before and after the economic crisis. After 2008, the national average employment growth rate dropped to 0.67 per cent from the pre-crisis level of 0.81 per cent per year. After the crisis, amongst the provincial metropolitan areas, only Cardiff and Sheffield were able to reach an above average employment growth rate, while Birmingham and Edinburgh were close to the national growth rate. Leeds, Nottingham and Liverpool performed well below the national average in the second half of the studied period. 
Figure 6 Differential growth of employment between 2000 and 2007 and between 2008 and 2014

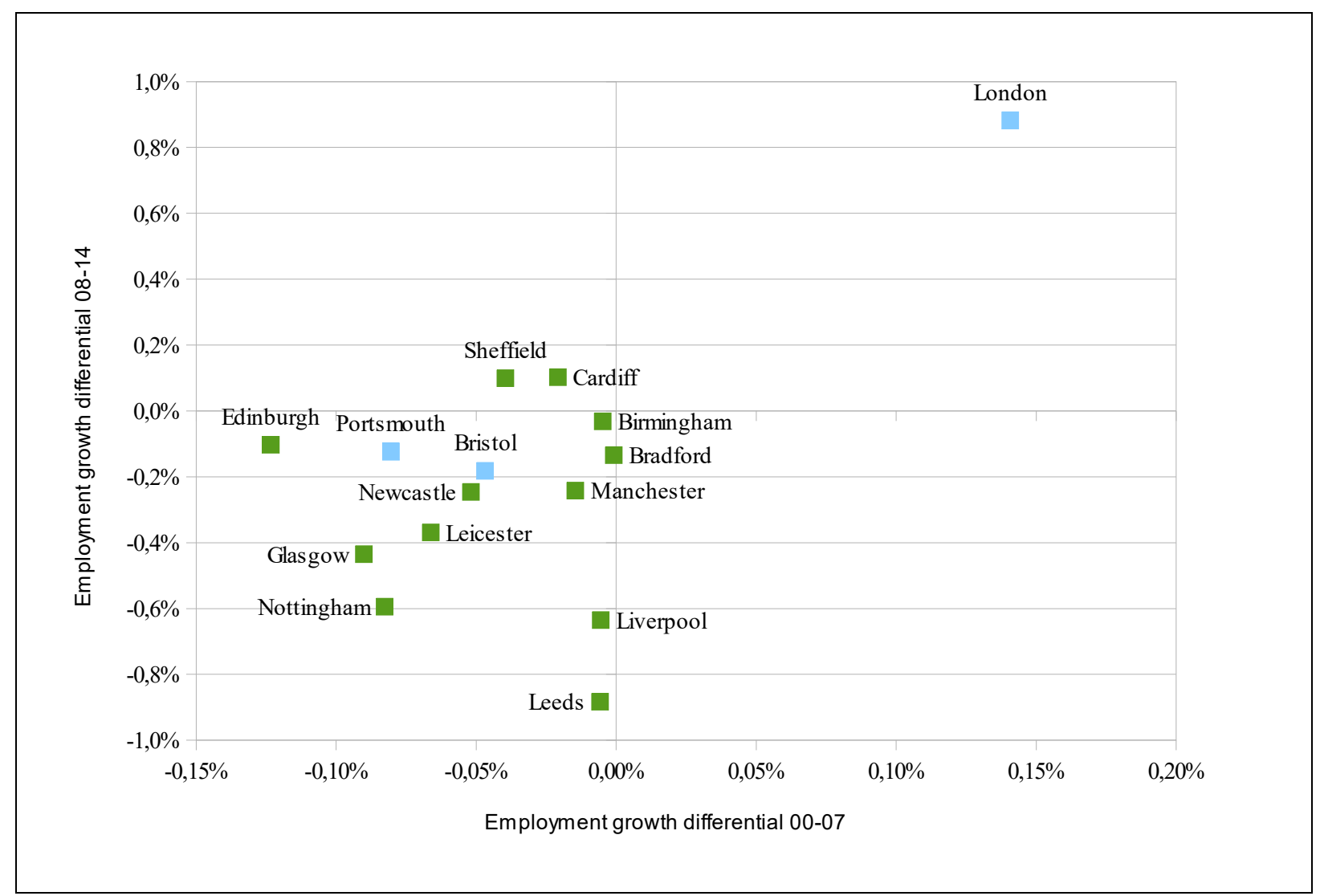

Source: Author's elaboration based on OECD data.

Note: Northern metropolitan areas: green colour, Southern metropolitan areas: blue colour. Zero values represent national average.

Our data and the literature raise doubts over the new conventional wisdom that the big cities are the engines of growth in the UK. Before 2000, big, provincial cities were regarded the main centres of job loss and population decline in Britain, whereas smaller towns and rural areas were seen as the main locations of growth. Novel researches point out that city size, per se does not guarantee growth (Martin et al., 2016, Fothergill and Houston, 2016). Even the largest provincial cities differ in their success in attracting knowledge-intensive industries, therefore a very different approach is required in different places (Centre for Cities, 2017a).

In 2013, the average labour productivity was 78296 US\$ in the UK according to the OECD data, which means that London, Edinburgh, Glasgow, Bristol, Manchester, Leeds and Birmingham performed better than the national average. Figure 7 verifies the previously mentioned statements that there is no straightforward relationship between productivity and city size in the United Kingdom. Analysing the data without London, the statistical link between the two variables becomes even weaker. Actually, the best performers behind 
London were Slough, Reading, Aldershot and Milton Keynes, all located in the vicinity of the capital city, while the only northern city was Aberdeen amongst the top 10 areas in terms of GVA per worker. The weakest productivity was measured in Blackpool, Blackburn, Stoke, Hull and Swansea, while even Sheffield is amongst the 10 cities with the lowest GVA per worker (Centre for Cities, 2017b). This phenomenon poses challenge for future regional economic stabilisation in the United Kingdom, since the main driver of long-run economic development is productivity. From a policy point of view, cities need to improve their ability to create new ideas and spread information, and the access they give businesses to many highly-skilled workers (Bessis, 2016).

Figure 7 Population (persons) and labour productivity (US\$) in the main metropolitan areas of the United Kingdom in 2013

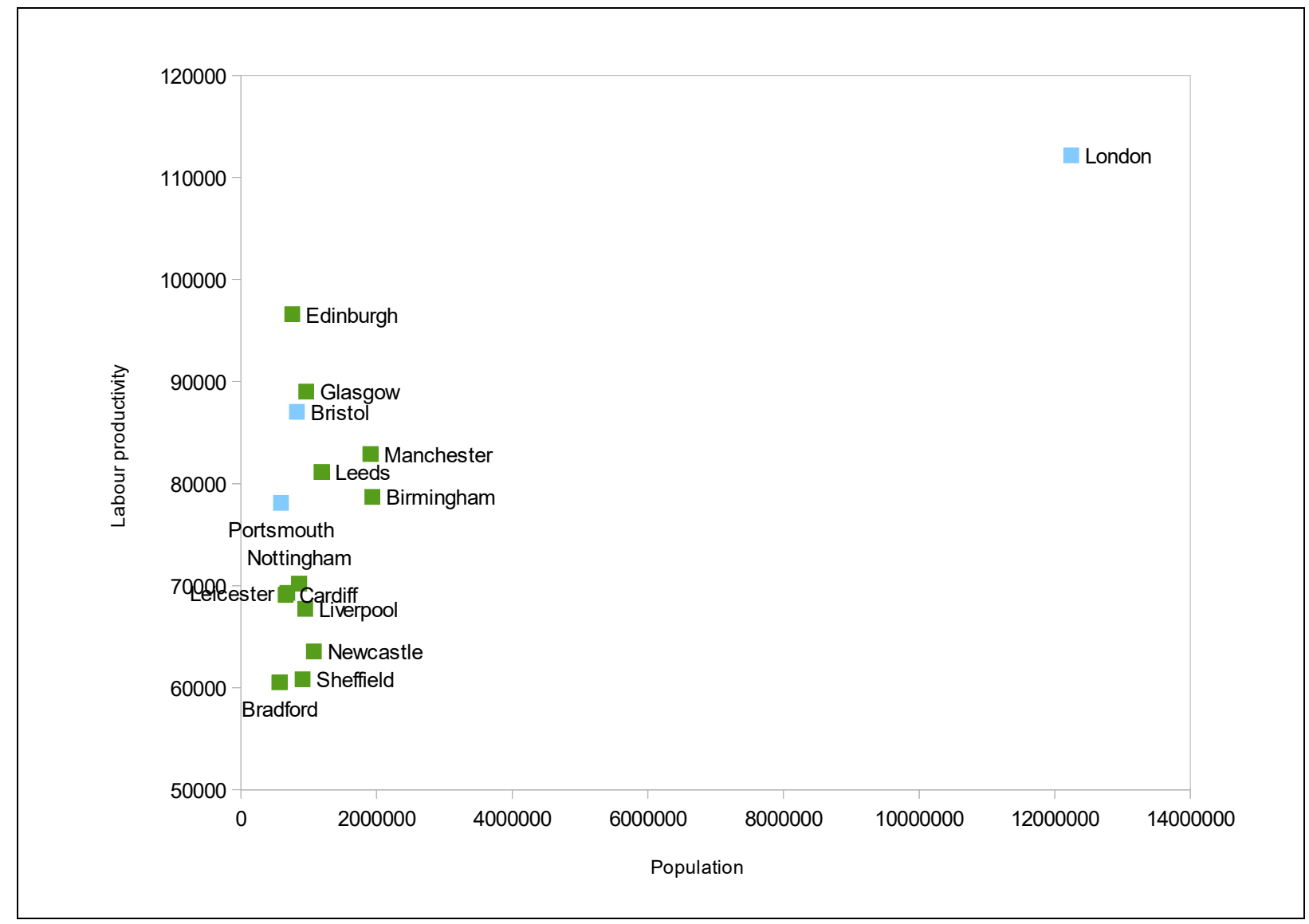

Note: Northern metropolitan areas: green colour, Southern metropolitan areas: blue colour.

Source: Author's elaboration based on OECD data.

McCann (2016) explains that the geography-productivity, geography-inequality story of the $\mathrm{UK}$ is much more of a regional core-periphery issue rather than it is an urban issue, that is, the performance of cities is largely dependent on the performance of the region in which they are located. The reason behind this is that the various linkages between London and the rest of the UK economy are both very weak and largely limited to the Southern regions of England 
(p. 357). For this reason, relying purely on the spillover effects of the buoyant South East would not solve the problems of the North, furthermore, some even argue that there are no such positive effects, at all.

\section{CONCLUSION}

The high level of regional inequalities in the United Kingdom poses the question whether the concentration of the economic prosperity in one corner of the country is good or bad for the nation as a whole. The economic policies are seeking the options to drive the country out of the recession after the second half of the 2000s, placing special emphasis on the issue of regional re-balancing. London is obviously leading the recovery and the growth of the whole national economy, but also the issue of unleashing the potentials of the cities and regions outside the Southeastern core areas have come to the fore again. Our study highlighted that in the UK, city size is not directly related to better productivity performance, rather, productivity benefits appear outside the largest Northern cities, mainly in the Southern regions.

As a consequence of the Brexit decision, the UK faces further economic challenges, and it has implications for the regions, as well. Concerning the geography of the EU referendum, the 'leave' campaign dominated mainly in the big northern cities of England, in Wales, across the Midlands, as well as the south and east of England. The vote for 'remain' had a high share in London, Scotland and Northern Ireland (see Fig. A2 in the Annex). These results reflect that not all regions of the country enjoy the advantages of globalisation. A positive shift in national policy can be detected after the referendum, since economic policy turned towards place-based strategies and emphasise the need for the growth everywhere around the country. Politicians articulated commitment towards the Northern Powerhouse and the Midlands Engine strategy, which is a favourable shift from former space-blind policies.

Our study reaffirms the view that relying purely on the spillover effects of the buoyant South East would not solve the problems of the North, furthermore, some even argue that there are no such positive effects, at all. Our conclusion is that current literature researches properly revealed the main problems behind the sub-optimal national economic performance and regional inequalities in the $\mathrm{UK}$, and assigned proper directions to improve them. However, despite important economic policy initiatives and steps towards devolution, current measures are not effective enough since they do not transform the basics of the UK's economic model. 


\section{Acknowledgement}

This study has been prepared with the support of the project No. K_120004 of the Hungarian National Research, Development and Innovation Office. The author is grateful for the two anonymous referees for their useful comments.

\section{REFERENCES}

Baker, A. R. H., \& Billinge, M.D. (eds.) (2004). Geographies of England: the North-South Divide - Imagined and Material. Cambridge, Cambridge University Press

Bell, D. N. F., \& Eiser, D. (2016). Migration and fiscal policy as factors explaining the labour-market resilience of UK regions to the Great Recession. Cambridge Journal of Regions, Economy and Society, 9, 197-215

Bessis, H. (2016). Competing with the continent. How UK cities compare with their European counterparts. Centre for Cites

Centre for Cities (2017a) Why don't we see growth up and down the country? [pdf] Retrieved from: http://brexit.regionalstudies.org/custom/uploads/2017/04/Centre-for-Cities-Whydont-we-see-growth-up-and-down-the-country.pdf

Centre for Cities (2017b) Cities Outlook 2017. Retrieved from: http://www.centreforcities.org/wp-content/uploads/2017/01/Cities-Outlook-2017Web.pdf

City Growth Commission (2014). Unleashing Metropolitan Growth. Royal Society for the Arts, London.

City of London Corporation (2011). London's Competitive Place in the UK and Global Economies. Research Report, City of London Corporation, London.

Dijkstra, L. (2013). Why investing more in the capital can lead to less growth. Cambridge Journal of Regions, Economy and Society 6, 251-268

Fothergill, S., \& Houston, D. (2016). Are big cities really the motor of UK regional economic growth? Cambridge Journal of Regions, Economy and Society, 9, 319-334.

Ganesh, J. (2015). Disunited kingdom: London in a world of its own, The Financial Times, 2 March, The Financial Times: London.

Gardiner, B. - Martin, R. - Sunley, P. - Tyler, P. (2013). Spatially unbalanced growth in the British economy. Journal of Economic Geography 13, 889-928.

Gardiner, B., Martin, R., \& Tyler, P. (2011). Does spatial agglomeration increase national growth? Some evidence from Europe, Journal of Economic Geography, 11 (6), 1-28.

Gordon, I. (2016). Quantitative easing of and International Financial Centre: how central London came so well out of the post-2007 Crisis. Cambridge Journal of Regions, economy and Society, 9, 336-353.

Gudgin, G., \& Schofield, A. (1993). The Emergence of the North-South Divide and its Projected Future. In: Harrison, R.T. - Hart, M. (eds.) Spatial Policy in a Divided Nation. Regional Policy and Development Series 2. Regional Studies Association, Jessica Kingsley Publishers Ltd., London

Hildreth, P., \& Bailey, D. (2013). The economics behind the move to 'localism' in England. Cambridge Journal of Regions, Economy and Society, 6, 233-249.

HM Government (2010). Local Growth: Realising Every Place's Potential, Cm 7961. HMGovernment.

HM Government (2017). Midlands Engine Strategy. Department for Communities and Local Government, March 2017

HM Treasury (2015). Fixing the foundations: Creating a more prosperous nation. July, 2015 Retrieved from: http://dera.ioe.ac.uk/23490/1/Productivity_Plan_web.pdf 
IPPR urges government to prioritise HS3 link. 8 August 2016. BBC News. Retrieved from: http://www.bbc.com/news/uk-england-37011839

Magnifico, G. (1973). European Monetary Unification. New York: John Wiley.

Marshall, M. (1990). Regional alternatives to economic decline in Britain's industrial heartland: industrial restructuring and local economic intervention in the West Midlands conurbation. In: Stöhr, W.B. (ed.) Global challenge and local response - Initiatives for economic regeneration in contemporary Europe. London, Mansell, pp. 163-198.

Martin, R. (2008). National growth versus spatial equality? A cautionary note on the new 'trade-off' thinking in regional policy discourse. Regional Science, Policy \& Practice 1 (1), $3-13$.

Martin, R. (2015). Rebalancing the Spatial Economy: The Challenge for Regional Theory. Territory, Politics, Governance, 3 (3), 235-272.

Martin, R., Pike, A., Tyler, P., \& Gardiner, B. (2015). Spatially rebalancing the UK economy: The need for a new policy model. Regional Studies Association, March 2015

Martin, R., Sunley, P., Tyler, P., \& Gardiner, B. (2016). Divergent cities in post-industrial Britain. Cambridge Journal of Regions, Economy and Society, 9, 269-299.

McCann, P. (2016). The UK Regional-National Problem. Geography, Globalisation and Governance. Routledge, Abingdon and New York

Osborne G. (2014). We Need a Northern Powerhouse. Speech delivered in Manchester 23 June. Retrieved from: https:/www.gov.uk/government/speeches/chancellor-we-need-anorthern-powerhouse, accessed 06 September 2016)

Overman, H. G. (2013). The Economic Future of British Cities. Centerpiece, Summer.

Rowthorn, R. (2010). Combined and Uneven Development: Reflections on the North-South Divide, Spatial Economic Analysis, 5:4, pp. 363-388

Smith, I. R. (2010). Relocation: Transforming Where and How Government Works. HM Treasury, London.

SQW (2016). The Northern Powerhouse Independent Economic Review. Retrieved from: http://www.transportforthenorth.com/wp-content/uploads/Northern-PowerhouseIndependent-Economic-Review-Executive-Summary.pdf

Sturgeon, N. (2014). Speech to Scotland's Business Sector, SSE Business Offices, Glasgow, Scottish Government 1 December, 2014.

Wilcox, Z., Nohrova, N., \& Bidgood, E. (2014). City views: How do Britain's Cities See London? Centre for Cities, London.

Zipf, G. (1949). Human Behavior and the Principle of Least Effort, Addison-Wesley, New York

Zsibók, Z. (2017). Continuing divergence after the crisis: long-term regional economic development in the United Kingdom. Regional Statistics, 7(1), 17-42. 


\section{Annex 1}

Figure A1. The map of the United Kingdom's cities with a population of more than 100 thousand people.

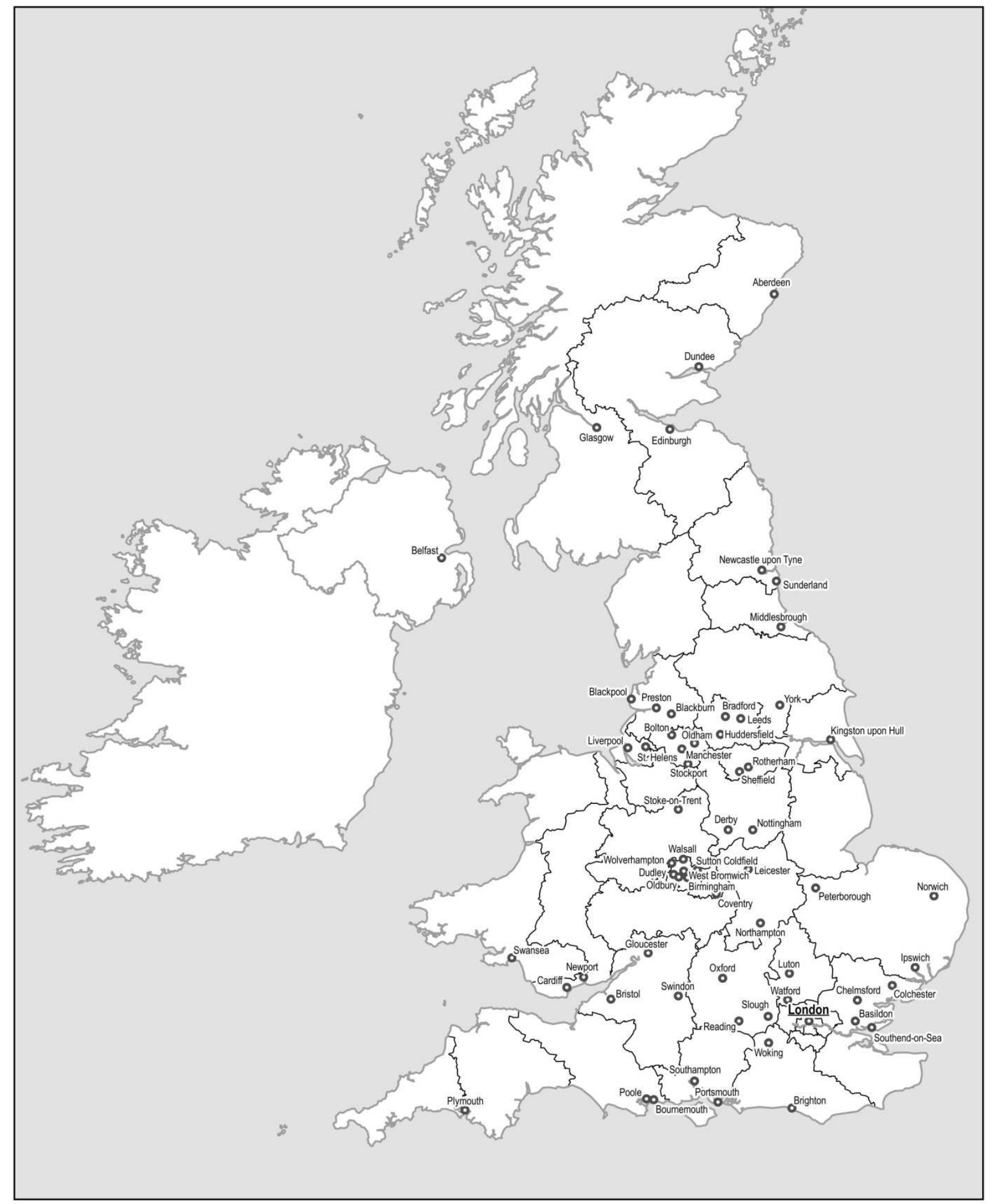

Source: Elaborated by Tamás Szabó, HAS-CERS based on the digital maps of Gfk GeoMarketing GmbH. 
Figure A2 The map of the EU referendum results concerning the UK leave the EU.

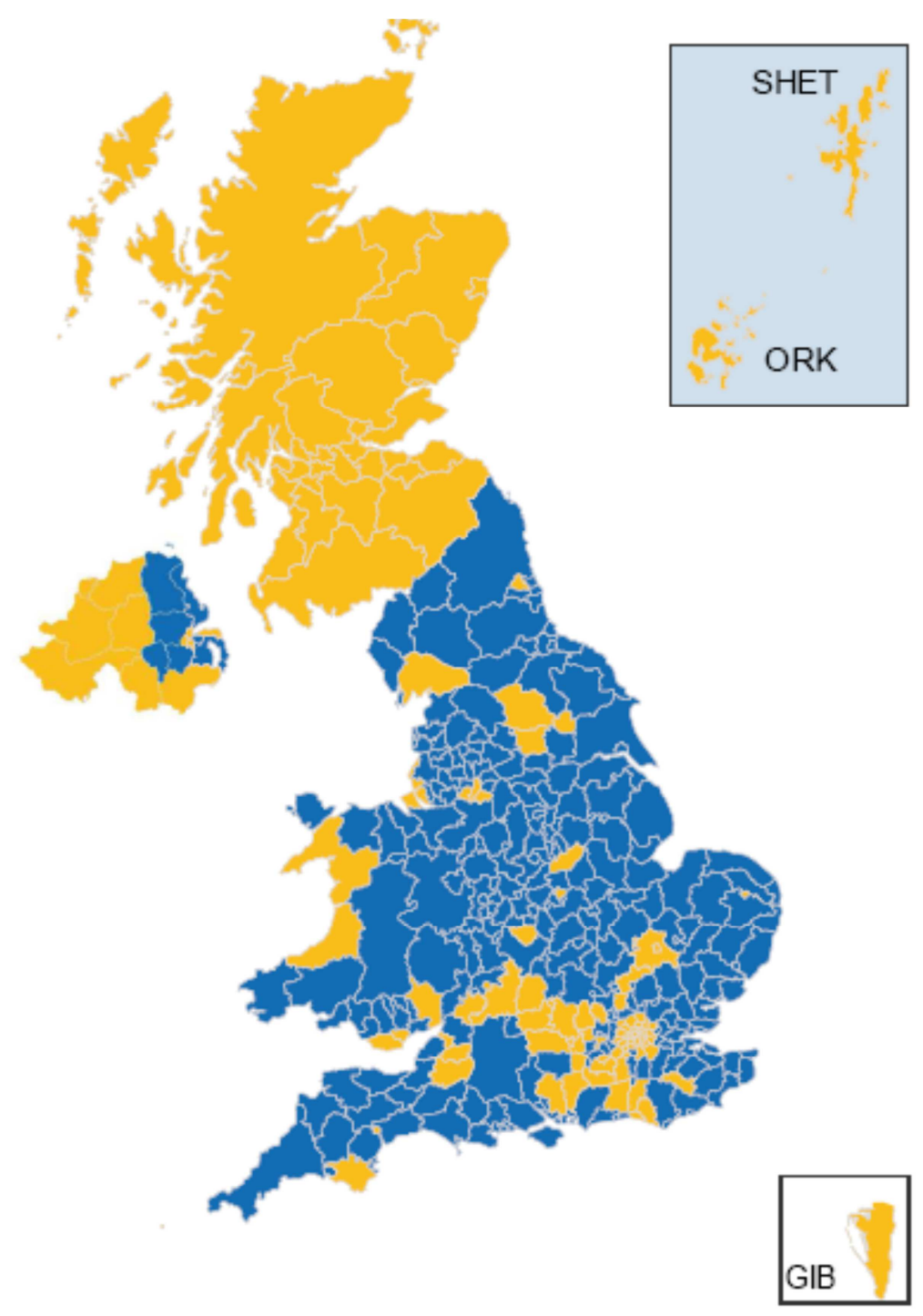

Note: blue colour: leave; yellow colour: remain.

Source: http://www.bbc.com/news/politics/eu_referendum/results. 